University of Nebraska - Lincoln

DigitalCommons@University of Nebraska - Lincoln

Faculty Papers and Publications in Animal

Science

Animal Science Department

1999

\title{
Effect of Dietary Phosphorus on Finishing Steer Performance, Bone Status, and Carcass Maturity
}

\author{
Galen Erickson \\ University of Nebraska-Lincoln, gerickson4@unl.edu \\ Terry Klopfenstein \\ University of Nebraska-Lincoln, tklopfenstein1@unl.edu \\ C. T. Milton \\ University of Nebraska-Lincoln \\ D. Hanson \\ University of Nebraska-Lincoln \\ Chris Calkins \\ University of Nebraska-Lincoln, ccalkins1@unl.edu
}

Follow this and additional works at: https://digitalcommons.unl.edu/animalscifacpub

Part of the Animal Sciences Commons

Erickson, Galen; Klopfenstein, Terry; Milton, C. T.; Hanson, D.; and Calkins, Chris, "Effect of Dietary Phosphorus on Finishing Steer Performance, Bone Status, and Carcass Maturity" (1999). Faculty Papers and Publications in Animal Science. 461.

https://digitalcommons.unl.edu/animalscifacpub/461

This Article is brought to you for free and open access by the Animal Science Department at DigitalCommons@University of Nebraska - Lincoln. It has been accepted for inclusion in Faculty Papers and Publications in Animal Science by an authorized administrator of DigitalCommons@University of Nebraska - Lincoln. 


\title{
Effect of Dietary Phosphorus on Finishing Steer Performance, Bone Status, and Carcass Maturity ${ }^{1}$
}

\author{
G. E. Erickson, T. J. Klopfenstein ${ }^{2}$, C. T. Milton, D. Hanson, and C. Calkins \\ University of Nebraska, Lincoln 68583-0908
}

\begin{abstract}
Yearling crossbred steers $(\mathrm{n}=60 ; 386$ $\mathrm{kg}$ ) were individually fed in a completely randomized experimental design to determine their $\mathrm{P}$ requirement. Treatments were in a factorial arrangement with two levels of $\mathrm{Ca}(.35$ or $.70 \%$ of $\mathrm{DM})$ and five concentrations of $\mathrm{P}(.14, .19, .24, .29$, or $.34 \%$ of $\mathrm{DM})$. The finishing diet consisted of $34.5 \%$ dry-rolled corn, $22.5 \%$ brewers grits, $22.5 \%$ corn bran, $7.5 \%$ ground corncobs, $5 \%$ molasses, $3 \%$ fat, and 5\% supplement. Supplemental P was provided as monosodium phosphate and $\mathrm{Ca}$ as limestone. Ash content was determined on the first phalanx bone from the lower front legs following slaughter, and rib bone breaking strength was determined with an Instron Universal Testing Machine. Carcass maturity and shear force were also evaluated on wholesale rib
\end{abstract}

cuts. Because no interactions between $\mathrm{Ca}$ and $\mathrm{P}$ levels were detected, only main effects are presented. Daily gain, DMI, and feed efficiency were not affected by dietary $\mathrm{P}$ concentration or $\mathrm{P}$ intake. Bone ash ( $\mathrm{g}$ or $\mathrm{g} /$ $100 \mathrm{~kg} \mathrm{BW})$ and rib bone breaking strength were also unaffected by dietary P. Feeding .7\% Ca decreased ( $P$ $<.06) \mathrm{ADG}$ and efficiency compared with feeding .35\% $\mathrm{Ca}$. Neither dietary Ca nor $\mathrm{P}$ had a significant effect on tenderness (shear force), skeletal maturity, or overall maturity. These results indicate that the $P$ requirement for finishing yearlings is .14\% of diet DM or less and that supplementing $\mathrm{P}$ above levels supplied by basal ingredients in many grain-based finishing diets is not necessary.

Key Words: Phosphorus, Requirements, Bones, Cattle, Carcasses, Performance

(C1999 American Society of Animal Science. All rights reserved.

J. Anim. Sci. 1999. 77:2832-2836

\section{Introduction}

Phosphorus is an expensive supplement in the diets of feedlot cattle and may be deleterious to the environment (Spears, 1996). Numerous studies have been conducted to elucidate the $\mathrm{P}$ requirement for maintenance (Lofgreen et al., 1952; Call et al., 1986) and gain (Wise et al., 1958; Miller et al., 1987; Jackson et al., 1988) of cattle. Most research has concentrated on young $(<5$ $\mathrm{mo})$, lightweight $(<200 \mathrm{~kg})$ calves that have elevated requirements due to bone growth and maturation. Ruminants utilize 60 to $70 \%$ of the organic $P$ they ingest, which in grains is primarily bound as phytate $\mathrm{P}$ (Nys et al., 1996). The phytate is hydrolyzed by phytase produced by ruminal microbes (Morse et al., 1992).

Because ruminants can utilize organic (phytate) $\mathrm{P}$, and most experiments have been conducted with younger calves gaining less than $.5 \mathrm{~kg} / \mathrm{d}$, $\mathrm{P}$ requirements for finishing yearling cattle deserve further attention.

\footnotetext{
${ }^{1}$ Published with the approval of the director as paper no. 12419 , journal ser., Nebraska Agric. Res. Div.

${ }^{2}$ To whom correspondence should be addressed.

Received November 30, 1998.

Accepted April 9, 1999.
}

Therefore, our objectives were 1) to determine the $\mathrm{P}$ required for growth and bone maintenance and 2) to determine the effects of dietary Ca:P ratios on performance and carcass characteristics of finishing yearlings.

\section{Materials and Methods}

Yearling crossbred steers $(\mathrm{n}=60 ; \mathrm{BW}=385 \pm 11 \mathrm{~kg})$ were individually fed once daily using Calan electronic gates (American Calan, Northwood, NH) from September 4 to December 18, 1996 ( 105 d). Steers were randomly assigned using a $2 \times 5$ factorial arrangement to 1 of 10 treatments ( 6 steers/trt). Treatments consisted of two levels of Ca, either .35 or .70\% of dietary DM with limestone as the source of supplemental Ca. Within each Ca level, diets contained five concentrations of $\mathrm{P}$ : either $.14 \%$, which contained no supplemental P, or .19, .24, .29 , or $.34 \%$ of dietary DM. Supplemental $\mathrm{P}$ was provided from monosodium phosphate $(\mathrm{NaP})$ instead of from dicalcium phosphate to allow the Ca level to remain constant at all concentrations of $\mathrm{P}$. Supplements (no $\mathrm{P}$ and high $\mathrm{P}$ ) for each $\mathrm{Ca}$ level were blended at the time of feeding to achieve appropriate concentrations of supplemental P.

Diets (Table 1) contained 34.5\% dry-rolled corn (DRC), $22.5 \%$ brewers grits, $22.5 \%$ corn bran, $7.5 \%$ ground corncobs, $5.0 \%$ molasses, $3.0 \%$ fat, and $5.0 \%$ supplement on 
Table 1. Diet composition (\% of diet DM); at time of feeding, the low- and high-P diets within calcium level were mixed to achieve targeted levels of dietary $\mathrm{P}$

\begin{tabular}{lcccc}
\hline \hline Item & $.14 \mathrm{P}-.35 \mathrm{Ca}$ & $.34 \mathrm{P}-.35 \mathrm{Ca}$ & $.14 \mathrm{P}-.70 \mathrm{Ca}$ & $.34 \mathrm{P}-.70 \mathrm{Ca}$ \\
\hline Dry-rolled corn & 34.5 & 34.5 & 34.5 & 34.5 \\
Corn bran & 22.5 & 22.5 & 22.5 & 22.5 \\
Brewers grits & 22.5 & 22.5 & 22.5 & 22.5 \\
Ground corncobs & 7.5 & 7.5 & 7.5 & 7.5 \\
Molasses & 5.0 & 5.0 & 5.0 & 5.0 \\
Fat & 3.0 & 3.0 & 3.0 & 3.0 \\
Supplement & & & & .7 \\
Finely ground corn & 2.1 & 1.7 & 1.2 & .73 \\
Sodium phosphate & - & .72 & 1.67 & -67 \\
Limestone & .75 & .75 & .30 & 1.35 \\
Salt & .30 & - & 1.34 & .46 \\
Urea & 1.30 & .32 & .46 & .02 \\
Potassium chloride & .46 & .02 & .02 & .01 \\
Trace mineral & & .02 & .01 & .02 \\
Vitamin premix $^{\mathrm{b}}$ & .01 & .02 & .02 & .01 \\
Rumensin premix $^{\mathrm{c}}$ & .02 & .01 & .01 & \\
Tylan premix $^{\mathrm{d}}$ & .01 & & & \\
\hline
\end{tabular}

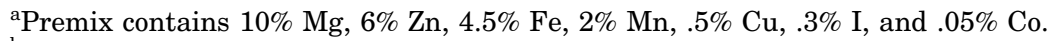

${ }^{\mathrm{b}}$ Premix contains $1,500 \mathrm{IU}$ vitamin A, 3,000 IU vitamin D, and 3.7 IU vitamin E per gram.

${ }^{\mathrm{c}}$ Premix contains $176 \mathrm{~g} / \mathrm{kg}$ monensin.

${ }^{\mathrm{d}}$ Premix contains $88 \mathrm{~g} / \mathrm{kg}$ tylosin.

a DM basis. Because DRC contains .25 to .30\% P, brewers grits and corn bran were fed to decrease the dietary $\mathrm{P}$ level to $.14 \%$. Both feedstuffs are high in energy and corn products; grits contain primarily cornstarch and bran consists of the digestible corn fiber. Diets were formulated for $12.0 \%$ protein and contained $31.7 \mathrm{mg} / \mathrm{kg}$ monensin and $10.4 \mathrm{mg} / \mathrm{kg}$ tylosin (Elanco Animal Health, Greenfield, IN).

Steers were adapted to treatment diets by limiting intake and gradually increasing DM offered until ad libitum intakes were attained. Steers were implanted on d 1 with Revalor-S (Hoechst Roussel, Somerville, NJ). Steers were housed in covered pens with 30 steers/pen. Weights were taken before feeding on three consecutive days at the beginning of the experiment for an average initial weight. To minimize variation in gastrointestinal tract fill, a common diet was fed for $5 \mathrm{~d}$ before initial weight determinations, with DMI restricted to $2 \%$ (DM basis) of BW $(7.7 \mathrm{~kg})$. Feed ingredients were sampled weekly and oven-dried for $24 \mathrm{~h}$ at $60^{\circ} \mathrm{C}$ for determination of DM. Ingredients were ground through a Wiley Mill (1-mm screen), composited by month, and analyzed for nitrogen with a nitrogen analyzer (Perkin Elmer, Norwalk, CT), and P. Feed P was analyzed with the alkalimetric ammonium molybdophosphate method ( $400 \mathrm{~nm}$; AOAC, 1996). Orts were collected when necessary to correct DMI. Final weights were calculated from hot carcass weight divided by a common dressing percentage (62). Liver abscess scores and hot carcass weights were recorded at slaughter. Livers were scored using a modification of the Elanco Products Company (1974) procedure, which was modified to include a fourth category for liver abscesses adhering to either the diaphragm or digestive tract (Stock et al., 1990). Quality grade, yield grade, and 12th rib fat thickness were recorded after a 36-h chill. Lean maturity, skeletal maturity, and overall maturity were assessed by a USDA meat grader.

Status of $\mathrm{P}$ in bone is a good indicator of whether the requirement for $\mathrm{P}$ has been met (Crenshaw et al., 1981). Because $\mathrm{P}$ is stored as hydroxyapetite crystals of calcium and phosphorus (Irving, 1963), an animal must degrade the entire complex to mobilize phosphorus. Bone characteristics are an important measure when determining $\mathrm{P}$ requirement, because bone resorption will maintain plasma $\mathrm{P}$ if dietary $\mathrm{P}$ is insufficient. At slaughter, two bones (first phalanx) were collected from each front leg for determination of total mineral content. After collection, each bone was trimmed of soft tissue and frozen until analysis. Phalanx bones were ashed for $24 \mathrm{~h}$ at $600^{\circ} \mathrm{C}$ for determination of total mineral concentration (AOAC, 1996).

Wholesale rib sections (IMPS 122A) were shipped to the University of Nebraska, aged for $7 \mathrm{~d}$, then frozen. One rib bone was collected from each rib section for determination of breaking strength. The rib bones were thawed and broken on an Instron Universal Testing Machine (model 1123, fulcra distance $=9 \mathrm{~cm}, 5 \mathrm{~mm} / \mathrm{min}$; Instron, Canton, MA) to measure bone strength. One steak ( $2.5 \mathrm{~cm}$ thick) was removed for tenderness assessment. Thawed steaks were cooked on a Farberware (Bronx, NY) Open Hearth broiler to an internal temperature of $70^{\circ} \mathrm{C}$ and cooled to approximately $21^{\circ} \mathrm{C}$, and 8 to 10 cores $(1.27 \mathrm{~cm}$ diameter) were removed parallel to fiber direction. The cores were sheared using a WarnerBratzler shear attachment to an Instron Universal Testing Machine.

Steer performance, bone characteristics, and carcass characteristics were analyzed as a completely randomized design using GLM procedure of SAS (1990). Animal was used as the experimental unit. Variables were tested 
Table 2. Main effects of dietary $\mathrm{P}$ and Ca concentrations on finishing performance

\begin{tabular}{|c|c|c|c|c|c|c|c|c|c|}
\hline \multirow[b]{2}{*}{ Item } & \multicolumn{6}{|c|}{ Phosphorus, \% of $\mathrm{DM}^{\mathrm{a}}$} & \multicolumn{3}{|c|}{ Calcium $\%$ of $\mathrm{DM}^{\mathrm{a}}$} \\
\hline & .14 & .19 & .24 & .29 & .34 & $\mathrm{SE}$ & .35 & .70 & $\mathrm{SE}$ \\
\hline Initial wt, $\mathrm{kg}^{\mathrm{b}}$ & 385 & 384 & 390 & 385 & 385 & 11 & 385 & 387 & 7 \\
\hline Final wt, $\mathrm{kg}^{\mathrm{b}, \mathrm{e}}$ & 567 & 553 & 568 & 566 & 545 & 15 & 568 & 552 & 10 \\
\hline $\mathrm{DMI}, \mathrm{kg} / \mathrm{d}^{\mathrm{b}}$ & 11.4 & 10.4 & 11.4 & 11.1 & 10.7 & .3 & 11.1 & 10.9 & .2 \\
\hline $\mathrm{ADG}, \mathrm{kg} / \mathrm{d}^{\mathrm{b}}$ & 1.76 & 1.62 & 1.71 & 1.75 & 1.53 & .09 & $1.76^{\mathrm{c}}$ & $1.59^{\mathrm{d}}$ & .06 \\
\hline
\end{tabular}

${ }^{\text {a No }} \mathrm{Ca} \times \mathrm{P}$ interaction was detected $(P>.90)$.

${ }^{\mathrm{b}}$ No significant linear, quadratic, or cubic effects due to $\mathrm{P}(P>.10)$.

${ }_{\mathrm{c}, \mathrm{d}}$ Means within row for Ca with different superscripts differ $(P<.05)$.

e Determined as hot carcass weight divided by $62 \%$ dress.

for a calcium $\times \mathrm{P}$ interaction; main effects were tested if no interaction between the two factors existed at $P>$ .10. If the F-test for the $\mathrm{P}$ main effect was significant at $P<.10$, then NLIN techniques (SAS, 1990) were used to determine the $\mathrm{P}$ requirement; otherwise, orthogonal contrasts for linear, quadratic, cubic, and lack of fit effects were tested.

\section{Results}

There were no interactions between $\mathrm{Ca}$ and $\mathrm{P}$ levels, so only main effects for $\mathrm{P}(\mathrm{n}=12)$ and $\mathrm{Ca}(\mathrm{n}=30)$ are presented. Dry matter intake, ADG, and feed efficiency were similar across P levels (Table 2). Intakes were variable due to individual feeding, but no consistent trends (linear, quadratic, or cubic) were evident due to $\mathrm{P}$ intake. Nonlinear regression was not conducted for DMI, ADG, and feed efficiency because of the lack of significant difference among nonlinear components due to dietary P. Steers fed $.70 \% \mathrm{Ca}$ had numerically lower DMI and gained slower $(P<.05)$ than steers fed $.35 \% \mathrm{Ca}$. Feed efficiency was also depressed $(P<.05)$ by feeding the higher level of Ca. No difference $(P>.10)$ in lean, skeletal, or overall carcass maturity scores or shear force value (meat tenderness) were detected among treatments (Table 3).
Bone density of the first phalanx bones, whether expressed as total grams of mineral or as a percentage of carcass weight, was unaffected by $\mathrm{P}$ level (Table 4). Rib bone area and breaking strength, expressed as area under curve or peak force in kilograms, respectively, were unaffected by P intake. Steers fed .70\% Ca did not have greater phalanx bone density or rib bone area. However, ribs from steers fed $.70 \%$ Ca required greater $(P<.10)$ peak force to break than ribs from steers fed .35\% Ca.

\section{Discussion}

Phosphorus required for maintenance is $1.6 \mathrm{~g}$ absorbed $\mathrm{P}$ per $100 \mathrm{~kg} \mathrm{BW}$, and $\mathrm{P}$ required for gain is 3.9 $\mathrm{g}$ absorbed $\mathrm{P}$ per $100 \mathrm{~g}$ retained protein (NRC, 1996). For the steers used in this experiment, the predicted $\mathrm{P}$ required for maintenance was $11.3 \mathrm{~g} / \mathrm{d}$, assuming $68 \%$ absorption (NRC, 1996). Phosphorus required for gain was predicted as $11.2 \mathrm{~g} / \mathrm{d}$, assuming $68 \%$ absorption and calculated average retained protein as $195.5 \mathrm{~g} / \mathrm{d}$ (NRC, 1996). Actual $P$ intakes calculated from corrected DMI and $\mathrm{P}$ concentration in feed ingredients ranged from 15.9 to $36.4 \mathrm{~g} / \mathrm{d}$. This suggests, contrary to industry perspective (Spears, 1996), that the NRC nutrient requirements for beef cattle overestimated $\mathrm{P}$ required by finishing yearlings. The industry average for $\mathrm{P}$ is .35 to $.39 \%$ of $\mathrm{DM}$

Table 3. Main effects of dietary P and Ca concentrations on carcass characteristics of finishing yearlings

\begin{tabular}{|c|c|c|c|c|c|c|c|c|c|}
\hline \multirow[b]{2}{*}{ Item } & \multicolumn{6}{|c|}{ Phosphorus, \% of $\mathrm{DM}^{\mathrm{a}}$} & \multicolumn{3}{|c|}{ Calcium, $\%$ of $\mathrm{DM}^{\mathrm{a}}$} \\
\hline & .14 & .19 & .24 & .29 & .34 & $\mathrm{SE}$ & .35 & .70 & $\mathrm{SE}$ \\
\hline Carcass wt, kg & 352 & 343 & 352 & 351 & 338 & 10 & 352 & 343 & 6 \\
\hline Marbling score ${ }^{\text {cd }}$ & 499 & 524 & 523 & 482 & 554 & 19 & 509 & 524 & 12 \\
\hline Fat thickness, $\mathrm{cm}^{\mathrm{b}}$ & 1.04 & 1.02 & 1.07 & 1.09 & 1.09 & .08 & 1.04 & 1.09 & .05 \\
\hline Shear force, $\mathrm{kg}^{\mathrm{b}}$ & 5.17 & 4.91 & 5.42 & 4.81 & 5.05 & .29 & 4.97 & 5.17 & .19 \\
\hline \multicolumn{10}{|l|}{ Maturity score $^{\text {be }}$} \\
\hline Skeletal & 60.8 & 49.2 & 57.8 & 53.3 & 51.7 & 3.9 & 56.7 & 52.5 & 2.5 \\
\hline Lean & 69.2 & 64.2 & 76.5 & 67.5 & 67.5 & 5.3 & 71.3 & 66.6 & 3.4 \\
\hline Overall & 64.2 & 54.2 & 64.8 & 59.2 & 57.5 & 3.6 & 62.0 & 57.9 & 2.3 \\
\hline
\end{tabular}

${ }^{\mathrm{a}} \mathrm{No} \mathrm{Ca} \times \mathrm{P}$ interaction was detected $(P>.10)$.

${ }^{\mathrm{b}}$ No significant linear, quadratic, or cubic effects due to $\mathrm{P}(P>.10)$.

${ }^{\mathrm{c}}$ Marbling score, where slight $50=450$, small $50=550$.

dSignificant cubic effect due to $\mathrm{P}(P<.05)$.

${ }^{\mathrm{e}}$ Maturity score expressed as percentage of A maturity. 
(Hoechst-Roussel Agri-Vet Company, 1996). The NRC (1996) estimates the P requirement as .20\% of DM, and these data suggest that the requirement is less than $.14 \%$. Burroughs et al. (1956) conducted a trial with a similar type of cattle receiving a $60 \%$ concentrate finishing diet and three levels of P: .18 (17.8 g/d), .25 (26.8 g/ d), or .33\% (35.4 $\mathrm{g} / \mathrm{d})$ of DM. The authors concluded that the $\mathrm{P}$ required for gain of $1.3 \mathrm{~kg} / \mathrm{d}$ was $.25 \% \mathrm{P}$, despite the fact that plasma concentrations were similar in cattle fed each treatment. Long et al. (1956) fed growing, yearling beef heifers P levels of .07, .11, and .15\% of DM and reported linear improvements in intake, gain, and plasma P. However, Call et al. (1978) fed growing heifers primarily hay diets at either $66(10.3 \mathrm{~g} / \mathrm{d})$ or $174 \%(26.1$ $\mathrm{g} / \mathrm{d}$ ) of NRC-predicted $\mathrm{P}$ requirements (NRC, 1978) for $2 \mathrm{yr}$ and observed no differences between dietary treatments in gain, body weight, intake, or calving performance.

A recent change in the USDA beef quality grading system disqualifies B-maturity carcasses with small amounts of marbling from the Choice grade. Concern has been expressed that mineral status of the diet might influence rates of skeletal ossification and(or) tenderness. The concentration of $\mathrm{Ca}$ and $\mathrm{P}$ in this study did not affect ossification of bone tissue used to evaluate skeletal maturity in beef carcasses. In the present study, dietary $\mathrm{Ca}$ and $\mathrm{P}$ concentrations were not related to meat tenderness. This result supports data by Oberbauer et al. (1988) in which four concentrations of Ca ranging from .37 to $1.8 \%$ of diet $\mathrm{DM}$ and $.42 \% \mathrm{P}$ were fed to growing lambs. They concluded that $\mathrm{Ca}$ fed at these levels had no effect on metacarpal bone growth. If dietary mineral status does influence skeletal maturation in cattle, it does not seem to be through the role of $\mathrm{Ca}$ or $\mathrm{P}$.

Calcium:phosphorus ratios fed in this study ranged from 1:1 to 5:1. Ricketts et al. (1970) evaluated three ratios of $1: 1,4: 1$, and $8: 1$ with young calves and concluded that performance was adversely affected at the 8:1 Ca:P ratio. Wise et al. (1963) evaluated ratios ranging from
$.4: 1$ to $14.3: 1$ with $114-\mathrm{kg}$ calves and concluded that the optimum ratios were from 1:1 to 7:1. The Ca:P ratios in our study were in the range of previously reported data for optimum animal performance.

In this study, the higher dietary Ca concentration decreased ADG and efficiency. Brink et al. (1984) observed an improvement in feed efficiency when limestone was increased in the diet from .8 to $1.7 \%$ of DM; however, the improvement was significant in one of five experiments, with a consistent small improvement in all experiments. Dowe et al. (1957) observed a decrease in ADG as $\mathrm{Ca}$ was increased in the diet from .4 to $2.6 \%$ of diet DM. Varner and Woods (1972) observed a linear improvement in ADG when Ca was increased from .20 to $.41 \%$ of diet DM but did not observe further improvement when $\mathrm{Ca}$ was increased to $.50 \%$ with steers fed a high-concentrate diet. Huntington (1983) fed .3, .6, .9, and $1.2 \%$ Ca with limestone as supplemental $\mathrm{Ca}$ and concluded that the optimum concentration of $\mathrm{Ca}$ was between .3 and $.6 \%$ with steers receiving an $85 \%$ concentrate diet. Huntington (1983) also observed an increase in blood $\mathrm{pH}$ and bicarbonate when dietary Ca was greater than .3\%. The improvement in gains typically observed with increasing $\mathrm{Ca}$ above the NRC requirement (.35\%; NRC, 1996) in finishing diets has been attributed to a buffering effect leading to fewer acidosis-related problems (Huntington, 1983). In the present study, the finishing diet contained $22.5 \%$ corn bran, resulting in less starch than would be typical in an $85 \%$ corn diet. Because less starch was being fed, acidosis may not have been a problem and any benefits from $\mathrm{Ca}$ buffering would not be evident.

Decreased gains at the high level of Ca could be attributed to less energy used for gain, because limestone replaced DRC, and the slightly lower intake would suggest less energy was available for gain. The low-Ca diet contained $2.05 \mathrm{Mcal} / \mathrm{kg}$ of $\mathrm{NE}_{\mathrm{m}}$ and $1.23 \mathrm{Mcal} / \mathrm{kg}$ of $\mathrm{NE}_{\mathrm{g}}$. Using the 1996 NRC model, an increase in DMI from 10.9 to $11.1 \mathrm{~kg}$ would result in an increase in ADG from 1.59 to $1.63 \mathrm{~kg}$. Clearly, the small decrease in DMI does

Table 4. Main effects of dietary P and Ca concentrations on bone ash and breaking strength of phalanx and rib bones from yearling carcasses

fed varying levels of $\mathrm{P}$ and $\mathrm{Ca}$

\begin{tabular}{|c|c|c|c|c|c|c|c|c|c|}
\hline \multirow[b]{2}{*}{ Item } & \multicolumn{6}{|c|}{ Phosphorus, \% of DM } & \multicolumn{3}{|c|}{ Calcium, \% of DM } \\
\hline & .14 & .19 & .24 & .29 & .34 & $\mathrm{SE}$ & .35 & .70 & $\mathrm{SE}$ \\
\hline \multicolumn{10}{|l|}{ Phalanx bone } \\
\hline $\begin{array}{l}\text { Total ash, g } \\
\text { Ash, g/100 kg }\end{array}$ & 28.3 & 27.5 & 28.9 & 27.5 & 28.5 & 1.0 & 28.0 & 28.3 & .6 \\
\hline hot carcass wt & 8.01 & 8.02 & 8.20 & 7.83 & 8.46 & .20 & 7.96 & 8.25 & .13 \\
\hline \multicolumn{10}{|l|}{ Rib bone } \\
\hline Bone area, $\mathrm{mm}^{2}$ & 275 & 262 & 267 & 269 & 283 & 10 & 269 & 273 & 7 \\
\hline $\mathrm{AUC}, \mathrm{mm}^{2} \mathrm{e}$ & 505 & 516 & 504 & 502 & 477 & 30 & 502 & 500 & 19 \\
\hline Peak, kg & 356 & 336 & 350 & 345 & 361 & 20 & $334^{\mathrm{c}}$ & $366^{\mathrm{d}}$ & 12 \\
\hline
\end{tabular}

${ }^{\mathrm{a}} \mathrm{No} \mathrm{Ca} \times \mathrm{P}$ interaction was detected $(P>.15)$.

${ }^{\mathrm{b}}$ No significant linear, quadratic, or cubic effects due to $\mathrm{P}(P>.10)$.

${ }^{\mathrm{c}, \mathrm{d}}$ Means within a column with different superscripts differ $(P<.10)$.

eArea under curve, area $=$ force $\times$ time for breaking strength.

${ }^{\text {f}}$ Peak force required to break rib. 
not explain the entire difference in gains between the two levels of dietary Ca. Accounting for substitution of DRC with limestone and the lower DMI resulted in an estimated increase in ADG to $1.65 \mathrm{~kg}$; however, the observed ADG of steers fed the lower level of $\mathrm{Ca}(.35 \%)$ was $1.76 \mathrm{~kg} / \mathrm{d}$.

All diets contained $3 \%$ added fat, and the interaction between fat and Ca level may result in less fat absorption with $.7 \% \mathrm{Ca}$ diets. The depressed fat absorption may result in lower $\mathrm{ADG}$ and feed efficiency with $.7 \% \mathrm{Ca}$. Bock et al. (1991) fed .6 and .9\% Ca with either 0 or $3.5 \%$ added fat and observed lower gain:feed and ADG with the high level of $\mathrm{Ca}$ and fat. The authors also observed no differences in performance between the two levels of Ca with no added fat. However, Zinn and Shen (1996) fed .45 and .90\% Ca with 0 or $5 \%$ fat and observed no effect on feedlot animal gain.

\section{Implications}

Corn-based finishing diets contain adequate $\mathrm{P}$ to meet a yearling steer's requirement for gain and bone reserves, because most grains contain .25 to .30\% P. Reducing dietary $\mathrm{P}$ concentration should not change maturity or tenderness attributes. Given the environmental concerns associated with $\mathrm{P}$, supplementation should not exceed animals' requirements to have a "safety" margin in diet formulation. Proper supplementation strategies of $\mathrm{P}$ will assist feedlots in becoming more environmentally sustainable.

\section{Literature Cited}

AOAC. 1996. Official Methods of Analysis (13th Ed.). Association of Official Analytical Chemists, Washington, DC.

Bock, B. J., D. L. Harmon, R. T. Brandt, Jr., and J. E. Schneider. 1991. Fat source and calcium level effects on finishing steer performance, digestion, and metabolism. J. Anim. Sci. 69:2211-2224.

Brink, D. R., O. A. Turgeon, Jr., D. L. Harmon, R. T. Steele, T. L. Mader, and R. A. Britton. 1984. Effects of additional limestone of various types on feedlot performance of beef cattle fed high corn diets differing in processing method and potassium level. J. Anim. Sci. 59:791-797.

Burroughs, W., A. Raun, E. Cheng, and C. C. Culbertson. 1956. Different kinds and amounts of phosphorus in fattening cattle rations. Iowa State College A.H. Leaflet 209:1-5.

Call, J. W., J. E. Butcher, J. T. Blake, R. A. Smart, and J. L. Shupe. 1978. Phosphorus influence on growth and reproduction of beef cattle. J. Anim. Sci. 47:216-225.

Call, J. W., J. E. Butcher, J. L. Shupe, J. T. Blake, and A. E. Olson. 1986. Dietary phosphorus for beef cows. Am. J. Vet. Res. 47:475-481.

Crenshaw, T. D., E. R. Peo, Jr., A. J. Lewis, and B. D. Moser. 1981. Bone strength as a trait for assessing mineralization in swine: A critical review of techniques involved. J. Anim. Sci. 53:827-835.
Dowe, T. W., J. Matsushima, and V. H. Arthaud. 1957. The effects of adequate and excessive calcium when fed with adequate phosphorus in growing rations for beef calves. J. Anim. Sci. 16:811-820.

Elanco Products Company. 1974. Tylan premix for beef cattle. Technical B Manual. pp 4-5. Indianapolis, IN.

Hoechst-Roussel Agri-Vet Company. 1996. The right combination ... revalor ${ }^{\circledR}$. Technical Bull. 2, 3, 5, 6, 7, 9 for revalor-h. Somerville, NJ.

Huntington, G. B. 1983. Feedlot performance, blood metabolic profile and calcium status of steers fed high concentrate diets containing several levels of calcium. J. Anim. Sci. 56:1003-1011.

Irving, J. T. 1963. Dynamics and functions of phosphorus. In: C. L. Comar and F. Bonner (Ed.) Mineral Metabolism. Vol. 2. p 249. Academic Press, New York.

Jackson, J. A., Jr., D. L. Langer, and R. W. Hemken. 1988. Evaluation of content and source of phosphorus fed to dairy calves. J. Dairy Sci. 71:2187-2192.

Lofgreen, G. P., M. Kleiber, and J. R. Luick. 1952. The metabolic fecal phosphorus excretion of the young calf. J. Nutr. 47:571-581.

Long, T. A., A. D. Tillman, A. B. Nelson, B. Davis, and W. D. Gallup. 1956. Dicalcium phosphate and soft phosphate with colloidal clay as sources of phosphorus for beef heifers. J. Anim. Sci. 15:1112-1118.

Miller, W. J., M. W. Neathery, R. P. Gentry, D. M. Blackmon, C. T. Crowe, G. O. Ward, and A. S. Fielding. 1987. Bioavailability of phosphorus from deflourinated and dicalcium phosphates and phosphorus requirements of calves. J. Dairy Sci. 70:1885-1892.

Morse, D., H. H. Head, and C. J. Wilcox. 1992. Disappearance of phosphorus from concentrates in vitro and from rations fed to lactating dairy cows. J. Dairy Sci. 75:1979-1986.

NRC. 1978. Nutrient Requirements of Beef Cattle (5th Ed.). National Academy Press, Washington, DC.

NRC. 1996. Nutrient Requirements of Beef Cattle (7th Ed.). National Academy Press, Washington, DC.

Nys, Y., D. Frapin, and A. Pointillart. 1996. Occurrence of phytase in plants, animals, and microorganisms. In: M. B. Coelho and E. T. Kornegay (Ed.) Phytase in Animal Nutrition and Waste Management: A BASF Reference Manual, 1996. pp 213-236. BASF, Mt. Olive, NJ.

Oberbauer, A. M., L. Krook, D. E. Hogue, W. B. Currie, and M. L. Thonney. 1988. Dietary calcium and metacarpal growth in ewes. J. Nutr. 118:976-981.

Ricketts, R. E., J. R. Campbell, D. E. Weinman, and M. E. Tumbleson. 1970. Effect of three calcium:phosphorus ratios on performance of growing Holstein steers. J. Dairy Sci. 53:898-903.

SAS. 1990. SAS/STAT ${ }^{\circledR}$ User's Guide (Version 6.06 Ed.). SAS Inst. Inc., Cary, NC.

Spears, J. W. 1996. Optimizing mineral levels and sources for farm animals. In: E. T. Kornegay (Ed.) Nutrient Management of Food Animals to Enhance and Protect the Environment. pp 259-275. CRC Press, Boca Raton, FL.

Stock, R. A., M. H. Sindt, J. C. Parrott, and F. K. Goedeken. 1990. Effects of grain type, roughage level and monensin level on finishing cattle performance. J. Anim. Sci. 68:3441-3455.

Varner, L. W., and W. Woods. 1972. Calcium levels in high grain beef cattle rations. J. Anim. Sci. 35:415-417.

Wise, M. B., A. L. Ordoveza, and E. R. Barrick. 1963. Influence of variations in dietary calcium:phosphorus ratio on performance and blood constituents of calves. J. Nutr. 79:79-84.

Wise, M. B., S. E. Smith, and L. L. Barnes. 1958. The phosphorus requirement of calves. J. Anim. Sci. 17:89-99.

Zinn, R. A., and Y. Shen. 1996. Interaction of dietary calcium and supplemental fat on digestive function and growth performance in feedlot steers. J. Anim. Sci. 74:2303-2309. 